\title{
Perspektif Ekologi Politik Kebijakan Pengelolaan Danau Limboto
}

\author{
Hasim \\ Fakultas Perikanan dan Ilmu Kelautan \\ Universitas Negeri Gorontalo \\ Gorontalo,Indonesia \\ Email: hasim@ung.ac.id
}

\begin{abstract}
The Limboto Lake is the largest lake in Gorontalo Province. These natural resources have biodiversity of fishery which become economic source of coastal lake community. Besides, the economic activity of aquaculture fishery also grows rapidly in Limboto lake. The Limboto Lake is the largest lake in Gorontalo Province. These natural resources have biodiversity of fishery which become economic source of coastal lake community. Besides, the economic activity of aquaculture fishery also grows rapidly in Limboto lake, The Limboto Lake has a strategic role for the province of Gorontalo. The Limboto lake degradation shows a more destructive of the area and the depth is reduced. This research study the product of law as a environmental politic instrument of the government and analyzes it in a political ecological perspective. The research design used descriptive quantitative and qualitative by using methodological approach of political ecology. The results show that regulation related to general management of the lake and Lake Limboto is particularly weak in the context of cohesiveness, harmonization, and problem focus.
\end{abstract}

Keyword: Political Ecologic; Policy; Limboto Lake

\begin{abstract}
Abstrak
Danau Limboto merupakan danau terbesar di Provinsi Gorontalo. Sumberdaya alam ini memiliki kakayaan hayati perikanan yang menjadi sumber ekonomi masyarakat pesisir danau. Disamping itu aktivitas ekonomi perikanan budidaya juga tumbuh pesat di danau Limboto. Danau Limboto merupakan danau terbesar di Provinsi Gorontalo. Sumberdaya alam ini memiliki kakayaan hayati perikanan yang menjadi sumber ekonomi masyarakat pesisir danau. Disamping itu aktivitas ekonomi perikanan budidaya juga tumbuh pesat di danau Limnboto. Danau Limboto memiliki peran strategis bagi provinsi Gorontalo. Degrdasi danau Limboto menunjukkan gambaran semakin destruktif yaitu luasan dan kedalamannya berkurang. Penelitian ini bertujuan untuk mengkaji produks hukum sebagai instrumen politik lingkungan pemerintah dan menganalisis dalam perspektif ekologi politik. Desain penelitian yang digunakan deskriptif kuantitatif dan kualitatif dengan menggunakan pendekatan metodelogis ekologi politik. Hasil menunjukkan bahwa regulasi terkait pengelolaan dananu secara umum dan danau Limboto secara khusus masih lemah dalam konteks keterpaduan, harmonisasi, dan fokus masalah.
\end{abstract}

Kata Kunci: Ekologi Politik; Kebijakan; Danau Limboto 


\section{PENDAHULUAN}

Danau merupakan sumberdaya alam strategis bagi pembangunan. Hal tersebut didasarkan atas fungsi danau yang multi dimensi bagi kelangsungan hidup, termasuk manusia. Diantara fungsi danau tersebut ada yang bersifat intagiable, sulit dilihat langsung namun memiliki peran besar. Oleh karena itu, pengelolaan sumberdaya danau harus dilakukan secara tepat agar fungsinya berjalan secara berkelanjutan.

Danau Limboto merupakan danau terbesar di Provinsi Gorontalo. Sumberdaya alam ini memiliki kakayaan hayati perikanan yang menjadi sumber ekonomi masyarakat pesisir danau. Disamping itu aktivitas ekonomi perikanan budidaya juga tumbuh pesat di danau Limnboto. Menurut Hasim dan Mopangga (2014) danau Limboto memiliki potensi ekonomi wisata yang besar sehingga prospek untuk dikembangkan. Pengembangan wisata danau didukung oleh bangunan sejarah tempat mendaratnya Ir. Soekarno Presiden RI pertama pada saat melawat ke Gorontalo, sehingga memberi nilai daya tarik lebih besar.

Sisi lain degradasi danau Limboto dalam berjalannya waktu semakin besar. Menurut Hasim et al., (2017) luasan perairan danau Limboto yang sesuai untuk kegiatan perikanan budidaya mengalami pengurungan sangat signifikan yaitu 8,03 ha $(0,36 \%)$. Hasim (2012) memprediksi dengan status sedimentasi eksisting maka tahun 2025 danau Limboto akan hilang. Hasim et al., (2011) menyatakan berdasarkan analisis multidimensi menunjukkan bahwa dimensi kelembagaan pengelolaan danau Limboto tergolong tidak berlanjut.

Pengelolaan danau Limboto didasarkan atas kebijakan pemerintah. Kebijakan tersebut dalam bentuk sistem peraturan perundangan sumberdaya alam Copyright $@$ 2018, Publik : (Jurnal Ilmu Administrasi), ISSN: 2301-573X (Print), ISSN: 2581-2084 (Online) dan lingkungan. Eric Wolf (1972) termasuk ilmuwan awal yang mencetuskan ekologi politik yaitu kesaling berpengaruhan antara sistem ekonomi politik terhadap masalah ekologis mencakup lingkungan dan aspek sosialnya. Marifa (2005) mencatat ada dua masalah aspek kebijakan dan kelembagaan pengelolaan sumberdaya alam di Indonesia yaitu inkonsistensi kebijakan dan lemahnya koordinasi. Kajian terkait aspek peraturan perundangan sebagai kebijakan konstitusional pengelolaan danau Limboto belum banyak dibahas. Oleh karena itu kajian ini bertujuan untuk mengidentifikasi peraturan perundangan dari tingkat pusat hingga daerah terkait danau secara umum dan danau Limboto secara khusus. Hasil penelitian ini diharapkan menjadi informasi penting terkait basis peraturan perundangan untuk perbaikan pengelolaan danau Limboto yang lebih efektif.

\section{METODE PENELITIAN}

Penelitian ini tergolong penelitian pustaka dengan menggunakan desain penelitian deskriptif kuantitatif dan kualitatif. Metode deskriptif ialah suatu penelitian yang tujuan utamanya untuk memberikan gambaran umum atas suatu keadaan. Pendekatan metodologis ekologi politik yang digunakan menekankan pada aspek kebijakan politik lingkungan dampaknya secara ekologis dan sosial. Data yang dikumpulkan bersifat sekunder mencakup produk peraturan pemerintah dari undang-undang hingga peraturan daerah oleh yang diterbitkan pemerintah Provinsi Gorontalo.

\section{HASIL DAN PEMBAHASAN}

Gambaran mengenai penanganan kerusakan yang terjadi di Danau Limboto dapat dilihat dari beberapa peraturan yang ada pada Tabel berikut : 
Tabel 1 Landasan hukum kebijakan pengelolaan Danau Limboto

\begin{tabular}{|c|c|c|}
\hline Peraturan Perundangan & Batas Yuridiksi & $\begin{array}{l}\text { Lembaga } \\
\text { yang } \\
\text { Berwenang }\end{array}$ \\
\hline $\begin{array}{l}\text { UU No } 5 \text { Tahun } 1990 \\
\text { Tentang Konservasi } \\
\text { Sumberdaya Alam dan } \\
\text { Ekosistem }\end{array}$ & $\begin{array}{l}\text { 1. Pelaksanaan kegiatan konservasi; } \\
\text { 2. Pola dasar dan pengaturan cara } \\
\text { pemanfaatan konservasi } \\
\text { sumberdaya; } \\
\text { 3. Pembinaan konservasi berkaitan } \\
\text { penegakan hukum. }\end{array}$ & $\begin{array}{l}\text { Pemerintah, } \\
\text { masyarakat } \\
\text { dan instansi } \\
\text { hukum }\end{array}$ \\
\hline $\begin{array}{l}\text { UU No } 41 \text { Tahun } 1999 \\
\text { Tentang Kehutanan }\end{array}$ & $\begin{array}{l}\text { 1. Pembentukan wilayah pengelolaan } \\
\text { hutan; } \\
\text { 2. Aktivitas perencanaan, } \\
\text { pengelolaan/pemanfaatan } \\
\text { penelitian dan pengembangan serta } \\
\text { pengawasan kehutanan; } \\
\text { 3. Rehabilitasi hutan; }\end{array}$ & $\begin{array}{l}\text { Pemerintah, } \\
\text { masyarakat } \\
\text { dan aparat } \\
\text { hukum }\end{array}$ \\
\hline $\begin{array}{l}\text { UU No } 7 \text { Tahun } 2004 \\
\text { Tentang Sumberdaya Air }\end{array}$ & $\begin{array}{l}\text { 1. Pola pengelolaan wilayah sungai; } \\
\text { 2. Perencanaan pengelolaan SDA; } \\
\text { 3. Koordinasi }\end{array}$ & $\begin{array}{l}\text { Pemerintah, } \\
\text { masyarakat } \\
\text { dan Dewan Air }\end{array}$ \\
\hline $\begin{array}{l}\text { UU No } 31 \text { Tahun } 2004 \\
\text { Tentang Perikanan }\end{array}$ & $\begin{array}{l}\text { 1. Rencana pengelolaan SDI, jumlah } \\
\text { penangkapan; } \\
\text { 2. Penyusunan sistem informasi SDI; } \\
\text { 3. Penelitian dan pengembangan SDI; } \\
\text { 4. Pengawasan. }\end{array}$ & $\begin{array}{l}\text { Pemerintah, } \\
\text { LSM, PT, } \\
\text { penegak } \\
\text { hukum }\end{array}$ \\
\hline $\begin{array}{l}\text { UU No } 32 \text { Tahun } 2004 \\
\text { Tentang Pemerintah } \\
\text { Daerah }\end{array}$ & $\begin{array}{l}\text { 1. Perencanaan dan pengendalian } \\
\text { pembangunan; } \\
\text { 2. Penyelengaraan pemerintahan; } \\
\text { 3. Pengelolaan SDA; } \\
\text { 4. Perencanaan RTRW. }\end{array}$ & $\begin{array}{l}\text { Pemerintah } \\
\text { provinsi dan } \\
\text { kabupaten/kota }\end{array}$ \\
\hline $\begin{array}{l}\text { UU No } 26 \text { Tahun } 2007 \\
\text { Tentang Tata Ruang }\end{array}$ & $\begin{array}{l}\text { 1. Pengaturan dan pembinaan } \\
\text { penataan ruang; } \\
\text { 2. Perencanaan pemanfaatan, } \\
\text { pengendalian dan pengawasan } \\
\text { ruang; } \\
\text { 3. Penyidikan }\end{array}$ & $\begin{array}{l}\text { Pemerintah, } \\
\text { masyarakkat, } \\
\text { PPNS }\end{array}$ \\
\hline $\begin{array}{l}\text { UU No } 32 \text { Tahun } 2009 \\
\text { Pengelolaan Lingkungan } \\
\text { Hidup }\end{array}$ & $\begin{array}{l}\text { 1. Menetapkan dan melaksanakan } \\
\text { RPPLH; } \\
\text { 2. Menetapkan dan melaksanakan } \\
\text { KLHS; } \\
\text { 3. Penegakan hukum. }\end{array}$ & $\begin{array}{l}\text { Pemerintah, } \\
\text { masyarakat, } \\
\text { instansi hukum }\end{array}$ \\
\hline $\begin{array}{l}\text { PERDA No } 1 \text { Tahun } 2008 \\
\text { Tentang Pengelolaan } \\
\text { Danau }\end{array}$ & $\begin{array}{l}\text { 1. Perencanaan, pemanfaatan dan } \\
\text { pengawasan; } \\
\text { 2. Kerja sama dan penegakan hukum }\end{array}$ & $\begin{array}{l}\text { Pemerintah } \\
\text { provisni/daerah } \\
\text { dan PPNS }\end{array}$ \\
\hline
\end{tabular}

Sumber : Studi Pustaka Aturan Perundangan Tentang Danau Limboto 
Kerusakan danau limboto sebagai suatu sumberdaya ekosistem bukanlah proses yang terjadi secara tunggal. Sedimentasi, tercemarnya air, pertumbuhan tanaman air yang tinggi di danau, merupakan fenomena yang terjadi di hilir permasalahan. Banyak hal yang menjadi latar belakang sehingga terjadi kerusakan lingkungan danau, dan hal tersebut berlangsung secara kompleks. Salah satunya ialah peraturan perundangundangan sebagai kebijakan pemerintah tentang pengelolaan sumberdaya alam dan lingkungan. Kebijakan pemerintah tentang pengelolaan sumberdaya alam dan lingkungan merupakan instrumen formal tentang arah dan prinsip dalam pembangunan terkait sumberdaya alam.

Analisis isi dilakukan terhadap peraturan tersebut di atas menyangkut tema konservasi ekosistem dan pengelolaan danau secara umum. Dua tema tersebut dijadikan sebagai indikator tentang keberpihakan suatu peraturan terhadap keberlanjutan sumberdaya alam secara umum dan danau secara khusus. Hasilnya disajikan pada Tabel 2.

Tabel 2 Analisi isi tema konservasi dan danau

\begin{tabular}{ccll}
\hline No & Peraturan/Perundangan & \multicolumn{2}{c}{ Tema } \\
\cline { 3 - 4 } & & Konservasi & Danau \\
\hline 1 & UU No 5 Tahun 1990 & 23 & 0 \\
2 & UU No 41 Tahun 1999 & 14 & 1 \\
3 & UU No 31 Tahun 2004 & 15 & 3 \\
4 & UU No 32 Tahun 2004 & 1 & 0 \\
5 & UU No 7 Tahun 2004 & 28 & 11 \\
6 & UU No 26 Tahun 2007 & 1 & 1 \\
7 & UU No 32 Tahun 2009 & 10 & 0
\end{tabular}

Sumber : Olahan Data Pustaka

Kerusakan danau limboto sebagai suatu sumberdaya ekosistem bukanlah proses yang terjadi secara tunggal. Sedimentasi, tercemarnya air, pertumbuhan tanaman air yang tinggi di danau, merupakan fenomena yang terjadi di hilir permasalahan. Banyak hal yang menjadi latar belakang sehingga terjadi kerusakan lingkungan danau, dan hal tersebut berlangsung secara kompleks. Salah satunya ialah peraturan perundangundangan sebagai kebijakan pemerintah tentang pengelolaan sumberdaya alam dan lingkungan. Kebijakan pemerintah tentang pengelolaan sumberdaya alam dan lingkungan merupakan instrumen formal tentang arah dan prinsip dalam pembangunan terkait sumberdaya alam.

Analisis isi dilakukan terhadap peraturan tersebut di atas menyangkut tema konservasi ekosistem dan pengelolaan danau secara umum. Dua tema tersebut dijadikan sebagai indikator tentang keberpihakan suatu peraturan terhadap keberlanjutan sumberdaya alam secara umum dan danau secara khusus. Hasilnya disajikan pada Tabel 2. 
Berdasarkan data pada Tabel 2 menunjukkan bahwa kata konservasi terbanyak terdapat pada UU No. 7 tahun 2004 yaitu 28 kata, UU No. 5 tahun 1990 terdapat sebanyak 23 kata konservasi, sedangkan UU No. 32 tahun 2004 terdapat 10 kata konservasi. Sama halnya dengan kata danau terbanyak terdapat pada UU No. 7 tahun 2004 yaitu 11 kata, sedangkan UU No. 32 tahun 2009, UU No. 32 tahun 2004 dan UU No. 5 tahun 1990 tidak terdapat kata danau.

Tabel 2 menunjukkan bahwa, satusatunya perundangan yang terbit sebelum era otonomi daerah ialah UU No. 5 tahun 1990 Tentang Konservasi Sumberdaya Alam dan Ekosistem. Peraturan tersebut belum secara tegas memberikan arahan kepada berbagai pihak terkait kebijakan pengelolaan konservasi sumberdaya danau secara umum dan secara khusus. Pada pasal 38 UU No. 5 tahun 1990 masih sangat umum terkait penyerahan kewenangan kepada pemerintah daerah. Disamping itu, UU tersebut belum memberikan ruang publik untuk terlibat dalam pengelolaan sumberdaya alam. Peran rakyat dalam pelaksanaan konservasi diarahkan oleh pemerintah, pasal 37. Hal tersebut memberikan gambaran pengelolaannya masih bersifat sentralistik sebagaimana regim yang berkuasa ketika itu. Visi dan misi UU ini adalah konservasi sumberdaya alam, meskipun hanya terbatas pada kawasan suaka alam.

UU No. 41 Tahun 1999 tentang Kehutanan dalam substansi pro-kapital, bersifat sentralistik dan berorientasi produksi (Sumardjono et al. 2011). Fungsi hutan dalam UU ini dibagi dalam tiga macam yaitu hutan konservasi, hutan lindung dan hutan produksi. Pasal 37 UU ini menjelaskan bahwa pemanfaatan hutan yang berfungsi lindung dan konservasi dapat dilakukan sepanjang tidak merusak fungsinya. Misalnya PP No. 6 tahun 2007 yang memberikan mandat bahwa pengelolaan hutan lindung diarahkan untuk pemanfaatan hasil hutan bukan kayu, tetapi ketentuan ini menjadi tidak jelas ketika pemerintah mengizinkan penambangan bawah tanah di kawasan lindung melalui Peraturan Presiden No 28 tahun 2011. Landasan operasional tersebut menggambarkan inkonsistensi tentang pemanfaatan hutan lindung. Realitanya banyak kawasan lindung termasuk hutan lindung tertekan oleh kepentingan ekonomi. Dengan demikian KEPRES No. 32 tahun 1990 tentang Kawasan Lindung, tidak akan efektif pelaksanaannya di lapangan karena tumpang tindih dengan aturan yang lainnya.

UU No 7 tahun 2004 terbatas pada air sebagai sumberdaya alam dalam pendekatan komoditas. Sebaliknya ekosistem dari sumberdaya air tersebut tidak dijelaskan secara konkret terkait konservasinya. Artinya peraturan yang bersifat tematik UU No. 7 tahun 2004 ini, hanya memandang air sebagai komoditas. Konsekuensinya ialah air dipandang sebagai modal ekonomi untuk dieksploitasi dalam rangka mendapatkan rente. Peraturan tersebut tidak membahas atau mengatur tentang air keterkaitannya dengan ekosistemnya serta interdependensi dengan lingkungannya. Padahal keberadaaan air dalam konteks jumlah dan kualitas sangat ditentukan oleh ekosistemnya. Hal tersebut sejalan dengan pernyataan Sanim (2010) bahwa UU No. 7 tahun 2004 lebih berpihak kepada swasta dan kurang memandang air dari dimensi sosial serta mengabaikan aspek kajian ekosistemnya. Menurut Sumarjono et al. (2011) UU ini memiliki kecenderungan pro-kapital yang ditunjukkan oleh peluang badan swasta untuk mengusahakannya. PP No. 37 Tahun 2012 Tentang Pengelolaan 
Daerah Aliran Sungai, sebagai peraturan yang lebih operasional belum secara eksplisit menjelaskan tentang pengelolaan danau, sebaliknya sangat umum sebagai bagian dari DAS. Misalnya belum ada pasal atau ayat satupun yang menjelaskan tentang pengelolaan danau.

UU No. 31 tahun 2004 Pasal 5 menjelaskan bahwa danau merupakan salah satu wilayah pengelolaan perikanan Republik Indonesia untuk penangkapan dan pembudidayaan. Penjelasan pasal 13 menyatakan bahwa, danau termasuk dalam kawasan konservasi terkait kegiatan perikanan. Namun secara eksplisit keterpaduan pelaksanaan konservasi belum diatur dalam batang tubuh UU ini, sementara keterpaduan penting dalam konservasi danau. Sisi lain menurut Sumardjono et al. (2011) secara umum UU ini pengelolaannya bersifat sentralistik. Walaupun dalam pasal 65 disampaikan tentang penyerahan urusan dan pembantuan umum tehadap pemerintah daerah tetapi tidak jelas rinciannya.

UU No. 32 tahun 2004 Pasal 17 menjelaskan secara umum hubungan antara pemerintah pusat dan daerah serta hubungan antar pemerintah daerah tentang pemanfaatan sumberdaya alam. Namun secara keseluruhan UU ini belum memberikan penjelasan hubungan antar pemerintah daerah menyangkut kegiatan konservasi. Padahal sering kali konflik terjadi antara pemerintah daerah disebabkan oleh persepsi terhadap batasan sumberdaya alam sangat administratif, sedangkan hakikat sumberdaya alam bersifat ekosistemik, sehingga sangat rancu jika didekati secara administrasi semata. Artinya UU ini secara formal memberikan kewenangan pemerintah daerah terhadap pengelolaan sumberdaya alam. Namun sisi lain secara bersamaan UU ini pendekatannya sangat formal dalam memahami batasan sumberdaya alam. Copyright ( 2018, Publik : (Jurnal Ilmu Administrasi), ISSN: 2301-573X (Print), ISSN: 2581-2084 (Online)
Akibatnya sering terjadi konflik kepentingan dan kewenangan terkait pengelolaan sumberdaya alam diantara pemerintah daerah. Misalnya kerusakan ekosistem perairan danau yang merupakan daerah hilir, jika pengendaliannya semata teknosentris melalui restorasi danau, maka tidak menyelesaikan permasalahan secara mendasar, karena akar masalah di bagian hulu tidak dikendalikan. Sisi lain kawasan hilir dan hulu berada pada daerah administrasi kabupaten/kota yang berbeda. Dengan demikian regim otonomi daerah gagal memperbaiki pola pemanfaatan sumberdaya alam yang ekstraktif. Kegagalan tersebut diantaranya disebabkan oleh (1) keterbatasan kapasitas SDM daerah sehingga belum efektif menjalankan mandat yang diberikan. Kondisi tersebut bisa berdampak pada biaya transaksi tinggi; (2) dominannya kekuatan politik kepala daerah yang berimplikasi pada lahirnya kebijakan yang berorientasi kepentingan jangan pendek.

UU No. 26 tahun 2007 tentang Penataan Ruang merupakan instrumen kebijakan dalam aspek perencanaan ruang secara umum termasuk danau. Dari Tabel 22 memberikan informasi bahwa, secara kuantitatif ada dua kata konservasi dan satu kata tentang danau. Substansi konservasi pada undang-undang ini ialah penataan ruang salah satunya diarahkan pada konservasi sumberdaya alam. Sedangkan danau dalam undang-undang ini dipandang sebagai kawasan lindung setempat mencakup sempadan sungai, sempadan pantai dan sempadan danau, penjelasan Pasal 5 ayat 2. Semangat yang tersirat dari undang-undang ini ialah pemanfataan sumberdaya alam harus dalam sistem perencanaan tata ruang yang mendorong keberlanjutan sumberdaya alam tersebut. Oleh karena itu danau yang memiliki fungsi strategis dimasukkan dalam kawasan lindung setempat. Dalam 
aturan operasionalnya dijelaskan ruang kawasan danau yang mencakupi; (1) shoreline (garis pantai danau) berjarak 1550 meter dari pasang tertinggi, (2) shoreline buffer (daerah penyangga danau), (3) shoreland protection area (kawasan perlindungan danau) yaitu sekurangkurangnya berjarak 50-100 meter dari pasang tertingi, (4) daerah budidaya. Penataan ruang tersebut ditujukan agar danau sebagai sumberdaya dapat terus menjalankan fungsinya.

Kebijakan penataan ruang secara substansi mencakup tiga isu pokok yaitu pola ruang yang terdiri atas kawasan budidaya dan lindung, struktur ruang dan kelembagaan. Dalam kenyataannya penataan ruang kawasan danau secara khusus dan wilayah secara umum banyak mengabaikan aspek prinsip keserasian fungsi ruang yang tujuannya untuk keberlanjutan sumberdaya alam. Indikasinya banyak aktivitas ekonomi dilaksanakan di area yang secara peraturan di larang misalnya di kawasan lindung seperti sempadan sungai dan danau serta kawasan lindung yang melindungi kawasan di bawahnya. Akibat dari perubahan fungsi penggunaan lahan dari lindung menjadi budidaya di daerah tangkapan air danau, maka berimplikasi negatif terhadap keberadaan danau sebagai hilir dari sistem DAS tersebut. Kebijakan penataan ruang di kawasan Danau Limboto belum mengindahkan secara efektif aturan yang ada. Misalnya dalam RTRW Provinsi diamanahkan bahwa Danau Limboto menjadi kawasan strategis. Sedangkan RTRW Kota Gorontalo mengidentifikasi bahwa Danau Limboto menjadi salah satu alternatif sumber air bersih, pengembangan wisata dan pengembangan perikanan. Namun implimentasinya banyak aktivitas pertanian dilaksanakan di lahan-lahan marginal, aktivitas ekonomi di sempadan danau dan sungai, serta aktvitas ekonomi di danau sehingga mereduksi keberlanjutan fungsi danau.

Implimentasi kebijakan tata ruang kawasan Danau Limboto harus diatur dalam bentuk peraturan daerah tentang tata ruang kawasan Danau Limboto yang terpadu. Oleh karena itu kehadiran aturan di tingkat daerah dalam bentuk RTRW Danau Limboto adalah penting untuk memberikan kejelasan lokus, fokus dan otoritas. Perda ini juga harus mampu mengidentifikasi setiap kebutuhan ruang stakeholders yang berada di kawasan Danau Limboto agar tidak terjadi tumpang tindih kepentingan. Misalnya kepentingan memulihkan atau merevitalisasi kawasan hutan minimal 30 persen dari luas DAS yang diperintahkan UU No. 26 tahun 2007 pasal 17 dan memulihkan sempadan danau sebagai kawasan lindung.

UU No. 32 tahun 2009 memiliki visi konservasi dan telah memberi ruang publik untuk berpartisipasi dalam pengelolaan lingkungan hidup. Misalnya pada penjelasan pasal 2 huruf $\mathrm{k}$ yaitu yang dimaksud dengan "asas partisipatif” adalah bahwa setiap anggota masyarakat didorong untuk berperan aktif dalam proses pengambilan keputusan dan pelaksanaan perlindungan dan pengelolaan lingkungan hidup, baik secara langsung maupun tidak langsung. Oleh karena itu, lembaga yang mempunyai beban kerja berdasarkan Undang-Undang ini tidak cukup hanya suatu organisasi yang menetapkan dan melakukan koordinasi pelaksanaan kebijakan, tetapi dibutuhkan suatu organisasi dengan portofolio menetapkan, melaksanakan, dan mengawasi kebijakan perlindungan dan pengelolaan lingkungan hidup. Selain itu, lembaga ini diharapkan juga mempunyai ruang lingkup wewenang untuk mengawasi sumber daya alam untuk kepentingan konservasi. 
UU No.32 Tahun 2009 juga menjelaskan dan mewajbkan Kajian Lingkungan Hidup Strategis (KLHS). Namun pelaksanaannya di lapangan masih sangat terbatas, karena mandat ini baru. Sisi lain, tantangannya ialah komitmen pemerintah terhadap pelaksanaan di lapangan. Misalnya disahkannya PP No. 10 tahun 2010 tentang Tata Cara Perubahan Peruntukan dan Fungsi Kawasan Hutan dan PP No.15 Tahun 2010 tentang Penyelenggaraan Penataan Ruang. Kedua peraturan tersebut sering dikalahkan oleh kepentingan politik, sehingga pertimbangan sosial-ekologi menjadi marginal.

Perda Provinsi Gorontalo No 1 tahun 2008 merupakan payung hukum pengelolaan Danau Limboto dalam konteks lokal. Perda ini belum secara jelas mengatur aspek kelembagaan pengelolaan danau untuk lestari. Hal tersebut ditunjukkan oleh saling tumpang tindihnya program dan kegiatan yang dilaksanakan di kawasan Danau Limboto. Sisi lain PERDA ini belum secara jelas bagaimana fungsi kelembagaannya dijalan yaitu aspek koordinasi dan aturan mainnya.

Tabel 1 dan uraiannya memberikan petunjuk bahwa isu tentang danau sebagai sumberdaya alam yang penting bagi kelangsungan kehidupan tidak cukup terwadahi secara signifikan dalam berbagai aturan yang ada. Belum ada peraturan yang secara tematik memiliki fokus dan lokus tentang kawasan danau. Hal tersebut memberi penjelasan bahwa perhatian pemerintah terhadap danau masih sangat kecil. Padahal secara sosial budaya bahkan ekonomi serta ekologi, banyak masyarakat yang tergantung terhadap danau. Danau dalam peraturan perundung-undangan di atas hanya menjadi topik komplementer dari tema penting yang dibangunnya. Oleh karenanya wajar jika kemudian hampir seluruh danau yang ada di Indonesia Copyright @ 2018, Publik : (Jurnal Ilmu Administrasi), ISSN: 2301-573X (Print), ISSN: 2581-2084 (Online) mengalami degradasi yang serius. Keberpihakan politik terhadap kelestarian danau sangat rendah dan hanya terbatas pada kepentingan ekonomi semata.

Uraian tersebut juga memberikan gambaran bahwa, peraturan perundangan tentang sumberdaya alam dan lingkungan masih sektoral. Peraturan yang mengatur tentang sumberdaya alam dan lingkungan secara terpadu belum ada. Implikasinya banyak ditemukan adanya tumpang tindih antara peraturan satu dengan yang lainnya. Kondisi tersebut potensial menimbulkan biaya ekonomi tinggi.

Hal lain dari uraian di atas ialah regim otonomi daerah gagal menginternalisasi paradigma pembangunan berkelanjutan dalam agenda-agenda politik ekonominya. Kerusakan lingkungan dan perubahan kawasan hutan yang terus terjadi mengkonfirmasi keadaan tersebut. Kondisi tersebut juga menggambarkan bahwa paradigma pembangunan berkelanjutan belum menjadi sesuatu yang prinsip dalam kebijakan ekologi politik pemerintah. Paradigma pembangunan berkelanjutan terjebak pada pilihan pertumbuhan ekonomi. Sementara sumberdaya alam dan lingkungannya dipandang semata modal pembangunan dan mengabaikan nilai intagible dan intrinsik. Berdasarkan uraian diatas memberikan arahan tafsran bahwa berbagai perarutan perundang-undangan yang ada tersebut di atas masih memberikan bias terhadap keberlanjutan ekologis dan sosial secara simultan. Menurut Satria (2007) jarak yang dekat antara masyarakat dengan negara dalam rejim desentralisasi tidak membuahkan kebijakan yang aspiratif dalam kontek pengelolaan sumberdaya alam. 


\section{PENUTUP}

Kesimpulan

Kebijakan pengelolaan danau secara umum masih berorientasi politik lingkungan sehingga lemah dalam politik aksinya. Kebijakan pengelolaan danau dalam berspektif ekologi politik masih lemah. Hal tersebut ditunjukkan oleh belum ada keterpaduan konteks dan substnasi pada regulasi yang ada. Kebijakan ekologi politik pengelolaan danau Limboto belum terkonstruksi secara terpadu dalam konteks kelembagaan, substansi dan regulasi. Implikasi lemahnya kebijakan ekologi politik menjadi factor pengungkit terjadinya degrdasi ekosistem danau Limboto berlangsung secara massif dan dalam waktu yang lama. Perda No.1 Tahun 2008 tentang pengelolaan Danau Limboto belum mengakomodir spirit pengelolaan secara terpadu. Implikasinya efektivitas pengelolaan danau Limboto masih lemah yang ditunjukkan oleh degradasi yang terus berlanjut.

Saran

Perlu ada reformasi peraturan perundang-undangan sebagai payung hukum yang menguatkan penyelamatan ekosistem danau di Indonesia. Perlu ada review PERDA No 1 tahun 2008 untuk diletakkan dalam spirit ekologi politik dan menegaskan ruang kolaboratf berbagai stakeholder dan keterpaduan kawasan.

\section{DAFTAR PUSTAKA}

Hasim. (2012). Desain kebijakan pengelolaan Terpadu dan Berkelanjutan Danau Limboto Provinsi Gorontalo. Disertasi IPB, Bogor.

Hasim, Sapei A, Budiharsono S, Wardiatno Y. (2011). Analisis

Keberlanjutan Pengelolaan Danau Limboto. Jurnal Hidrosfer

Indonesia. Vol. 6
Hasim, Koniyo Y, Kasim F. (2017). Suitable location map of floating net cage for environmentally fish farming development with Geographic Information Systems applications in Lake Limboto, Gorontalo-Indonesia. $\quad A A C L$ Bioflux, 10 (2), pp. 254-264.

Marifa I. (2005). Institutional Transformation for Better Policy Implementation and Forcement. In in Resosudarmo (edt): The Politics and Economics of Indonesia's Natural Resources. ISEAS, Singapore.

Sanim B. (2011). Sumberdaya Air dan Kesejahteraan Publik. IPB Press, Bogor.

Satria A. (2007). Ekologi Politik dalam Ekologi Manusia. Fakultas Ekologi Manusia IPB, Bogor.

Sumardjono MSW, Ismail N, Rustiadi E, Damai AA. (2011). Pengaturan Sumberdaya Alam di Indonesia antara yang Tersurat dan Tersirat. Yogyakarta: Gadjah Mada University Press. 